\title{
Madrasah Quality Management Evaluation Case Study of Bogor MTS N 2
}

\author{
Opik Abdurrahman Taufik ${ }^{1}$, Sumarni², Wahid Khozin ${ }^{3}$, Farida Hanun ${ }^{4}$, Hayadin ${ }^{5}$, Iyoh Mastiyah ${ }^{6}$, Elis \\ Lisyawati $^{7}$ \\ taufikrachman74@gmail.com¹, marni_ch@yahoo.com.au²,wah_zinmi@gmail.com³,hanumjkt2@gmail.com ${ }^{4}$, \\ hayadin006@gmail.com ${ }^{5}, \underline{\text { mastiyah9@gmail.com }}$,
}

\author{
Research \& Development and Training Agency, MoRA ${ }^{1,2,3,4,5,6}$ \\ Universitas Nahdlatul Ulama Indonesia ${ }^{7}$
}

\begin{abstract}
The existence of madrasas is so important in creating national cadres who are Islamic-minded and have a high nationalism spirit. One of the advantages possessed by madrasa is the integration of general science and religious knowledge, therefore its management requires special attention and must be quality-oriented in all its aspects. MTsN Babakansirna Bogor Regency is one of the madrasas that implements quality management in the management of education. As a model madrasa, MTsN Babakansirna has a quality program ranging from planning, process, and educational output. Madrasa quality improvement and quality management strategies have been widely studied and researched, for example from the hostel model, financing strategies, graduate quality, community participation, Quality Function Development system, and others. However, it is still very rare to discuss the evaluation of the implementation of the strategy as a whole. Even though the evaluation becomes important as an assessment to take the next steps that need to be continuously adjusted to the times. Through field surveys, interviews, and study studies of quality management evaluation data were analyzed by triangulation techniques using a qualitative approach. Madrasa management is seen from three main aspects, namely: First, access to education services (education expectations, students, curriculum, human resources, and infrastructure). Second, governance (leadership and funding). And third, community participation. Based on the findings in the field, the quality management planning, process and outputs of the three aspects carried out by the MTsN Babakansirna Bogor have been done well, but they have not been maximized due to constraints in facilities, personnel, and limited funds.
\end{abstract}

Keywords: Evaluation, quality management, governance, society participation.

\section{Introduction}

Along with the development of an increasingly competitive society, educational organizations are demanded to be able to provide or produce quality products. Products in educational organizations are primarily in the form of services which include; communication, credibility, security, customer knowledge, standards, response reliability, access, and manners. Quality of service has several characteristics or characteristics, including; subjective, generally effective size, prioritizing attention, consisting of non-material - can be in the form of 
reputation, attitude, manners, etc., can not be calculated quantitatively, but can only be trusted, trusted and so on (Ariani, 1999: 9) .

In-Law number 20 of 2003 concerning the National Education System in article 50 paragraph (3) it is stated: The Government and/or Regional Government shall administer at least one education unit at all levels of education to be developed into an international standard education unit. Paragraph (1) and paragraph (2) of this article are regulated further by government regulation. Sounds paragraph (1): Management of the National Education system is the responsibility of the Minister (meaning the Minister of National Education). Paragraph (2): The government determines national policies with national education standards to guarantee the quality of national education.

Quality education, in the sense of a system consisting of quality education inputs, quality learning process, quality outputs, and quality outcomes. In turn, graduates who are in line with the expectations and needs of the community, both in personal quality, morals, knowledge and work competence become an absolute requirement in a global society that increasingly high levels of competition (Sukmadinata 2006: 51).

However, experience so far shows that the various programs implemented have provided hope for the continuity and control of the quality of Indonesian education during the crisis. Because the management is too rigid and centralized, the program has not had much positive impact, the national education participation rate and the quality of education continue to decline. Allegedly this is closely related to management problems.

According to Azis Wahab (2011: 58), the presence of model schools is more due to the demands of quality community needs because: (1) Existing schools are still felt to be unable to develop children's potential and abilities optimally, (2) Demands and challenges to the competitiveness, competing abilities that children will face in life in the third millennium (21st century), (3) Changes in orientation and development paradigms, all of which serve as strong reasons for the presence of a superior school system, (4) The era of globalization which is full of hopes and challenges that demands every nation to strive forward.

The declining quality of educational institutions such as schools is closely related to the malfunctioning of educational institutions in preparing the future generation of the nation optimally. This fact is also inseparable from all elements of education itself such as the role of parents, teachers, infrastructure, education managers and other educational stakeholders. Therefore it is necessary to consider the possibility of looking for breakthroughs that can lift the quality of our education, especially the basic education model which is the beginning of the formation of quality human resources.

Once the importance of school quality is important, the writer must research management improvements in other pilot schools so that they can produce quality graduates who also hope to provide benefits to anyone who wants to improve the quality of schools especially the secondary level.

Research on school quality has been widely carried out. According to Slamet (Tilaar, 2000: 14) to be able to produce good quality, there are four basic efforts that must be done in educational institutions, namely: (1) Creating a "win-win" situation and not a "losing" situation -wins" among interested parties with educational institutions (stakeholders); (2) The need to develop intrinsic motivation in everyone involved in the process of achieving quality; (3) Every leader must be oriented to the process and long-term results, so that the application of integrated quality management in education is not a process of short-term change, but a long-term effort that is consistent and continuous; (4) In mobilizing all the abilities of educational institutions to achieve the specified quality, cooperation must be developed between the elements of the process actors achieving quality results. 
At the level of Madrasah Aliyah, Muhibbin Syah (2009) found that MAN model students in Bandung are garrisoned, it will be more effective and can provide optimal services so that it becomes an Islamic school education that is in line with trends in the world of work/entrepreneurship and can be in accordance with college study programs. high country height

Meanwhile Supraptono (2008) found that the participatory leadership of school principals, school culture, change management, teacher work motivation, and Teacher Commitments related to teacher performance with a detracting coefficient of $74.7 \%$ and for the participatory leadership roles of principals, cultural schools, management changes, teacher work motivation, and teacher commitment to learning achievement of $67.5 \%$.

The Madrasa quality improvement strategy has also been approved: (1) using the QFD Quality Function Deployment system. This tool can help parents and translate them into activities that will be carried out by madrasas to improve the quality of schools. School people do not need to invite parents to school and even prefer parents can be asked for opinions through a questionnaire (Munadi 2011). (2) in terms of financing management (Sumarni 2012). (3) achievement standards (Sumarni 2013) (4) madrasa organization (Sopandi, 2011) (5) madrasa council (Lisadiyah, 2009).

Various efforts and strategies in improving the quality of madrassas have been widely applied in many places, especially public madrassas that are labeled as models, as well as research on quality improvement are easily found, but research on evaluating the implementation of quality management as a program is still not widely done. This is important to see the effectiveness of the implementation of the overall strategy.

This research was conducted at the Madrasah Tsanawiyah Negeri (MTsN) Babakansirna Model Leuwisadeng District, Bogor Regency. The selection of research objects was based because this madrasa was made a model madrasa in Bogor Regency. Since its establishment in 1964, this madrasa is the IAIN lab-school which was then made a model by the Ministry of Religion. In Bogor district, there are only 4 Tsanawiyah-level Madrasas with a state status of a total of 335 institutions. Each madrasa certainly has its quality management to improve the quality of their education.

Of the 1250 MTsN students, some students from outside Bogor study in this madrasa, even though geographically it is located about $35 \mathrm{~km}$ from the municipality. Several achievements have been made (general and religious) showing their ability to compete with other schools.

This study discusses how to evaluate the quality management of Education Access Services, Governance and community participation in MTsN 2 Bogor in realizing the madrasa model.

Evaluation of quality management in educational institutions (madrasas) can be known from the planning, process and output management. Through field surveys, documentation studies and in-depth interviews with stakeholders (parents of students) and madrasa managers, data are obtained which are then triangulated. In this evaluation research used a qualitative approach that aims to gain an understanding, holistic (holistic), interpretation of meaning, which is contextual. The use of this approach is adjusted to the research objectives of describing and identifying and reviewing the management of the Babakansirna State Madrasah which has a label model, as well as the efforts and constraints in realizing the school's goals. In this case, the researcher acts as the main instrument of data collection and the subject under study is positioned to have the same relative position as the researcher.

Evaluation of quality management research is conducted into independent variables, that is, without making comparisons or linking with other variables (Sugiono, Bandung: 2002). 
Variables raised in this study. 1) Educational access services; 2) Governance; and 3) Community participation.

\section{Results and Discussion}

The global era with a very rapid rate of change resulting in many future uncertainties that will be passed, this requires every organization to prepare themselves in facing it. In connection with educational institutions such as Hoy and Miskle (2001) schools, the need for schools to become learning organizations (Learning Organization), Hoy and Miskel (2008: 32) illustrates:

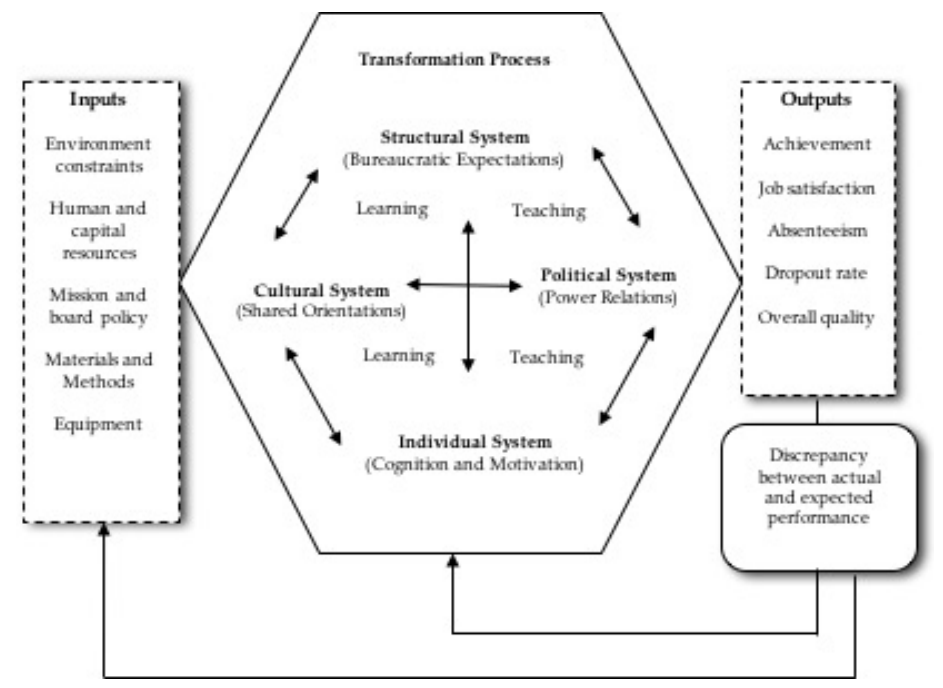

Figure 1: School component.

The picture above can be simply explained that as a social system the school organization is an organization whose function is to transform inputs into outputs. In this process, some factors influence each other, namely structural factors, individual factors, political factors, and cultural factors. Thus, in seeing a school organization, it seems that a systemic mindset is needed considering that each subsystem in it influences the transformation process that occurs, and this process will determine the quality of output produced by the school.

Educational institutions in the strict sense can be interpreted as a school or madrasa. Engkoswara (2002: 55) defines school as follows: effective schools can be interpreted as schools that show the expected level of performance in organizing the learning process, by showing quality learning outcomes to students by their main tasks.

Jaap Scheerens (2003) explains that effective schools have five important characteristics, namely: (1) strong leadership; (2) emphasis on achieving basic abilities; (3) a comfortable environment; (4) high expectations on student achievement; (5) and regular assessment of the programs made by students.

The quality management principles stated by Sujiatmo (2003) as follows: (1) customer focus means that the organization / educational institution, especially primary schools, 
depends on the customer. Therefore schools must understand the needs of current and future customers, understand customer requirements and try to truly meet customer expectations. (2) leadership; that is to say the leader in compiling school goals must be able to create and maintain an internal environment in such a way that each person becomes fully involved in achieving the school's goals. (3) involvement of personnel, meaning their full involvement which enables the use of staff capabilities to benefit the school. (4) process approach; it means that the desired results can be achieved better if the activities and related resources are managed as a process. (5) a systems approach, which means identifying, understanding, and managing all related processes as a whole will contribute to the effectiveness and efficiency of schools in achieving goals. (6) continuous improvement, meaning that schools must be able to achieve the goals that have been set on an ongoing basis. (7) fact approach to making decisions, meaning that effective decisions are based on the analysis of information data. (8) a mutually beneficial relationship with partners means mutual need between the school and partners, will increase the ability of both parties to produce value.

Madrasas as Islamic educational institutions in Indonesia are relatively younger than Islamic boarding schools. He was born in the 20th century with the emergence of the Manba'ul Ulum Madrasah in the Kingdom of Surakarta in 1905 and the Adabiyah School founded by Sheikh Abdullah Ahmad in West Sumatra in 1909. Madrasas stood on the initiative and realization of the reform of the existing Islamic education system. Madrasas as Islamic educational institutions are now placed as school education in the national education system.

In-Law number 20 of 2003 concerning the national education system, which is included in the madrasa education group is; Raudlatul Athfal / Bustanul Athfal (RA / B) in early childhood, Madrasah Ibtidaiyah (MI) and Madrasah Tsanawiyah (MTs) in basic education, and Madrasah Aliyah (MA) in secondary education.

The existence of madrasas is so important in creating national cadres who are Islamicminded and have a high nationalism spirit. One of the advantages possessed by madrasa is the integration of general science and religious science (Subhan, 2005). Madrasas are also an important part of national education institutions in Indonesia. His role was so great in producing the nation's next generation. Madrasa struggle to get this recognition is not easily obtained. Because before the existence of this institution less attention when compared with public schools. madrasa seems to only be a complement to the existence of national education institutions.

The word "madrasah" comes from Arabic from the root words "darasa", "yadrusu", "darsan", and "madrasatan" which means learning. The word madrasa (مدرسة) in Arabic is a form of the word "place information" (zharaf makan) which means "place of learning", or "place to give lessons". From the root of the word "darasa" it can also be derived from the word "midras" (مدرس) which means "books learned" or "place of study"; the word "al-midras" is also interpreted as "home to study the Torah". (Abu Luwis, 221).

Technically formal in the teaching and learning process between madrasas and schools do not have differences, but in Indonesia madrasas are not necessarily understood as schools, but given a more specific connotation, namely "religious schools", places where students get learning the things or the ins and outs of religion and religion (Islam) (Fadjar, 1998: 111-112)

According to Stufflebeam there are four types that can be reviewed from an evaluation so that it becomes a decision taken, namely: (1) Context Evaluation, resulting in "planning decisions or planning decisions", (2) Evaluating Inputs, producing "decision-making strategies or structuring decisions", ( 3) Process Evaluation, produce "implementing decision", and (4) Product Evaluation, produce "recycling decision" (Stufflebeam \& Coryn, 2014) 
As mentioned above, in this quality management evaluation research the author sees from 3 (three) aspects which are categorized as the main topics, namely, first, access to education services that include educational expectations as reflected in the vision and mission, students, curriculum, human resources, and facilities infrastructure. second, madrasa governance which includes the leadership of madrasa principals and madrasa financial management. and third, looking at community participation that contributes to the delivery of education in madrasas.

MTsN 2 Bogor is designated as a model madrasa with the following functions (1). That is, the MTsN Model is a standard arrangement of all aspects of MTs academic programs, the quality of education, the qualifications of madrasah principals and teachers, madrasah facilities, operational and madrasa management; (2). The training function, namely that the madrasa headmaster and master teacher must provide periodic training to school principals and MTs teachers in their target area; (3). The leadership function is that the MTsN Model is a leader or coach in various activities of MTs in the target area; (4). The function of educational facilities services, namely that the educational facilities owned by the MTsN Model are used as educational support facilities for MTs in their target area; (5). The function of supervision or supervision, namely that the madrasa head and master teacher or MTsN Model coach must conduct supervision or supervision of the implementation of education in the madrasa fostered. (6). The function of Professional Services is that through the MTsN Model madrasa heads, teachers and all madrasa staff have the opportunity to grow into professional education personnel.

\subsection{Education Access Services}

The needs and expectations of the community for good quality education services appear to be a major factor in innovation or renewal of quality management in education. Decisions made by the principal and staff and educational stakeholders to improve the quality of school services to the community will greatly influence innovation in the field of education management.

Like an education institution in general, the Babakansirna Leuwisadeng Model MTsN which (now in 2016) has changed to MTsN 2 Bogor has an ideal vision and mission. The vision and mission are formulated through consultation with the teachers, committees and madrasa stakeholders. So be a vision written and posted in several places, such as the principal's office, teacher's office, front of the office and near the gate. The vision is written, "Based on Faith and Taqwa, MTsN 2 Bogor Becomes an Excellent Primary Education Unit in Science and Charity". Every vision is written always accompanied by mission 8 (eight) items below, namely :

- Creating innovative and transparent Madrasah management;

- Organizing an effective, creative and innovative education so that students develop optimally;

- Creating a dynamic and conducive working environment;

- Creating a healthy, harmonious, safe and comfortable Madrasa condition and environmentally sound;

- Fostering the spirit of excellence of madrasas in their work, exploring their potential and achievement;

- Improving the quality of Islamic education through the actualization of the values of Religion and Nation's culture; 
- Giving birth to graduates who are qualified in Science and can answer future challenges;

- Developing collaboration of all education stakeholders with innovative and transparent management..

The socialization of the school's goals through the vision and mission has been carried out both verbally and non-verbally, to all those involved in the madrasa ranging from teachers, students, employees, community and other stakeholders. But they rarely know how it is implemented, and some teachers and students and employees pay little attention to it. Even though the vision and mission of the school is something to be achieved in an educational institution.

The number of MTsN 2 Bogor students is not directly proportional to the classroom where they are studying. Though the main interest of students is a comfortable learning process. In this process the teacher is expected to become a facilitator with multiple tasks, namely determining the teaching material and determining how the material is realized. In this process, students are situated in a learning atmosphere that guarantees quality.

Of the 446 new students who registered for the 2017-2018 school year, only 400 students were accepted after undergoing a series of tests, namely academic tests, reading the Qur'an and interviewing. At present (2017) there are a total of 1239 MTsN2 Bogor students consisting of 401 class VII students, 409 class VIII students, and 429 class IX students.

The selection process for madrasah student admissions shows quality in terms of input. Suyatno (2003) stated the characteristics that show quality students are: (1) students who are persistent, diligent, disciplined, innovative, creative and responsible. (2) does not mean that students immediately provide answers to questions or problems encountered. They actually tend to postpone answers until they are sure to have collected as much information as possible that guarantees satisfying answers.

MTsN 2 Bogor students are familiarized with reading the Quran before 5-10 minutes before the lesson begins. This is done to form a strong faith and balance of emotional intelligence. Likewise, the students' rules are quite strict starting from the uniforms, when entering and leaving the classroom, resting makes students more independent. Suyatno further revealed that to arouse students' rationality in formulating problem-solving, the characteristics of the teaching and learning process must include:

- Stirred his curiosity through sincere questions.

- Confronted with concrete problems and guided to solve them

- Question and answer that is harmonious and democratic

- Teachers together seek knowledge through problem-solving

- Look for many answers as alternatives

- Assessment submitted to students

- Involve students in totality (Suyatno: 2003).

As a public school that is characterized by religion, MTsN 2 Bogor applies the same curriculum as public schools, only the religious content is higher, namely $60 \%$ public and $40 \%$ religious.

The use of the 2013 curriculum has been running since 2016 with reference to the Ministry of National Education and the Ministry of Religion. These two models were adapted into the MTsN curriculum model. However, the difficulty is when teachers who have been certified are required to focus on the subjects they teach for at least 24 hours. For general subjects, it is 
not too much of a problem because the reference is from the Ministry of Education and Culture, only for religious family subjects must be innovated with local content as a hidden curriculum to strengthen and characterize madrasa modeling.

To provide optimal results of teaching and learning activities, it is necessary to use multi methods, multimedia, and multi evaluations. Whereas innovative teaching and learning activities can use an approach; active, creative, effective, efficient and fun learning (PAKEM). However, the existing infrastructure at MTsN 2 Bogor does not fully support student learning support facilities. For example, classrooms with a size of $7 \times 8 \mathrm{~m}$ are intended for 32 students, but in reality, more than the designation is used. Likewise, one toilet should be used for 15 people, but it is not yet proportional to the number of students available. This certainly needs to get more attention so that the carrying capacity of infrastructure can be optimal.

An effective madrasah must also describe how the principal can support the development of children, can work together with the teachers and delegate tasks that are possible to the teacher. Actively with the teacher to plan academic activities. Teachers are consistent in carrying out their activities, by preparing an action plan that can be guided by their students, can arouse motivation and build students' imagination, so that they can solve problems faced by students. Teachers can use the environment as a source of learning and use feedback to improve performance. The teacher is accustomed to focus his work on a certain subject matter so that students understand deeply each subject. The teacher places students as learning partners so that maximum communication and educational interaction occurs between them. Teachers and school principals can involve parents in developing activity plans and their implementation, to create positive working relationships and climate.

The board of teachers in the MTsN Model Babakansirna Leuwisadeng totaling 52 people consisted of 35 PNS teachers and 17 non-PNS teachers, while 35 PNS teachers already had S1 or $100 \%$ Bachelor Degree qualifications, and had educator certificates (certification). Whereas the total non-permanent teachers (honorary) totaling 17 already have S1 academic qualifications or $100 \%$ Bachelor Degree, but only 7 teachers or $49 \%$ who have other educator certificates (certification) are still on the waiting list. It is expected that before the end of time stipulated in Law Number 14 of 2005 concerning teachers and lecturers, non-PNS MTsN Model Babakansirna Leuwisadeng teachers who have not been certified have participated in the teacher competency improvement program, thus enabling the quality of education to increase as well because in addition to academic qualifications they must also have an educator certificate obtained through teacher certification. While the madrasa head certificate in the Babakansirna Model MTsN has not yet been held because before the appointment of the madrasa head in 2010 the government had not yet implemented a training program for prospective principals/madrasas. On one hand the government demands to implement regulations, but on the other hand schools/madrasas need a leader to account for the delivery of education.

Terroristically the teacher or school/madrasah who has been certified means that they are already professional in carrying out the learning task. Thus, teachers who already have competence are certainly professional in their respective fields of work, but it is not as easy as we imagine it means if the teacher has been certified the quality of education will improve, of course, there are still many other factors that influence the improvement of the quality of education for example, such as curriculum, teachers, students, infrastructure, supervision, motivation, and others.

\subsection{Governance}


The quality of management or management of education is a strategy or way of service in the organization of an organization or educational institution carried out by a leader and can provide satisfaction to the community or its customers both internally and externally. This strategy or method of service can be carried out by various parties such as school principals, teachers, students, and other resources involved in school activities.

In the management of MTsN 2 Bogor led by a madrasa head assisted by six assistant madrasah heads (PKM), namely PKM in the field of curriculum, representatives of PKM in the field of curriculum, PKM in the field of students, PKM representatives in the field of students, PKM in the field of infrastructure, and PKM in the field of public relations .

Being the head of the Madrasah MTsN 2 Bogor is not something easy, because it has to go through several procedures and tests from the Ministry of Religion as its guiding institution. But more important than that is the leadership ability and flexibility of insight in leading an educational institution.

Head of MTsN 2 Bogor Babakansirna Leuwisadeng said that leadership is the main point in organizing madrasa organizations. All problems with running a madrasa can be overcome properly if the madrasa head has the skills to choose the right way and approach in moving his staff and employees to achieve their goals. The Head of MTsN 2 Bogor Babakansirna Leuwisadeng was able to position himself as the facilitator of everyone and bridge the communication gaps between staff and departments.

According to the Head of the Leuwisadeng Model MTsN democratic leadership is one of the efforts he uses in managing human resources in madrasas. Besides that, the madrasa head must protect all groups, become the mother of all parts of the unit, not become a threat or something scary. Togetherness is the spirit that must be maintained in order to achieve the vision of the madrasa.

A madrasa head is not a head of the office who always sits behind desk signing papers and taking care of mere administrative matters. If that is what is meant by the duties of the headmaster, how nice and easy it is. Of course, this should not happen, the madrasa head must understand very well the main tasks and functions as a competent madrasa head. To become a madrasa head, it must be creative and innovative so to find and appoint a madrasa head who is creative and competent must be passed well in accordance with applicable regulations, in this case the head of MTsN 2 Model Babakansirna Leuwisadeng runs the authorization of the madrasa head referring to Government Regulation No. 13 of 2007 .

To achieve the quality of education management, it is expected that the role of parents is also very large in giving students the success of reasoning, especially their attention when they are learning and doing activities at home. Thus, the quality of education management carried out by a school principal can be seen from: (1) how a school principal actively involve parents in the education process. (2) how to do teamwork. (3) how is the suitability of the services provided with the needs of the community especially parents of students, and (4) how the principal conducts the feedback process continuously so as to provide satisfaction to the community or parents of students?

In 2015, MTsN 2 Bogor won an award in terms of the best financial management in West Java Province. This shows the accuracy, transparency, and accountability of financial management in supporting education in the madrasah.

However, in its implementation, it is quite a burden because all students are exempt from fees or free. Some of the needs for madrasa activities always invite the deliberative committee to produce solutions. In the Madrasah Activity Budget Plan, the facilities and infrastructure needed only come from the School Operational Assistance (BOS). Madrasas are not permitted to ask for financial assistance, let alone collect fees or fees from parents. Usually, the 
headmaster of madrasas in meeting the needs of the madrasas conducts cross-subsidizing efforts (cooperatives, committees, and grandmothers) optimally.

\subsection{Society Participation}

Malcolm S. Greenwood and Helen J. Gaunt (1994: p.26) say that what is meant by quality is meeting customer requirements, fitness for purpose and perhaps even delighting our customers. Here it is stated that a product or service is considered to be of quality if it can recognize the will of the customer, the goals are achieved well, and can satisfy the customer. Schools are said to be of good quality if the community finds what they are looking for and expected from, and they feel satisfied with the services provided. The satisfaction obtained by the community (students' parents) on school performance if their children obtain values that are beneficial to their lives and learning outcomes with good scores from all subjects given at school.

It is only natural for parents and community participation to be responsible for the development and improvement of the quality of madrassas, cannot rely solely on government assistance in the intellectual life of the nation

In essence, quality is the goal to be achieved by every organization, both in terms of inputs, processes, and outputs that are objectively measured (tangible) and those based on subjective assessments (intangible). According to Sallis, the development of quality in the world of education as a planned and sustainable effort only began in the late eighties (Sallis: 1993). From the management point of view are as follows: (1) strong leadership from the principal, (2) vision, mission, goals and objectives, and school planning, (3) school monitoring activities, (4) evaluation of school activities.

In MTsN 2 Bogor, community participation is channeled through madrasa committees formed in schools. The madrasa committee is representative of the students' parents at every level. It's just that the activities are not optimal because only once a year they hold activities, namely when the new school year. The school program was delivered and agreed on several activities in a new school year.

Community participation can be through channels and fields, for example in every educational activity, whether through monitoring, program evaluation, learning evaluation activities, extracurricular activities, and others. 
Overall the discussion of the above research is illustrated in the following table :

Table 1: Quality management evaluation aspects of MTsN 2 Babakansirna Bogor

\begin{tabular}{|c|c|}
\hline Aspect & Evaluation/Assessment \\
\hline $\begin{array}{l}\text { 1. Educational Access Services: } \\
\text { a. Community Expectations } \\
\text { (vision and mission) } \\
\text { b. Students (Screening (Tests) } \\
\text { for new students) } \\
\text { c. Curriculum (Using Religion } \\
\text { and general curriculum) } \\
\text { d. HR (Teacher and } \\
\text { Administrative Staff) } \\
\text { Recruitment of select } \\
\text { teaching and education } \\
\text { personnel } \\
\text { e. Facilities for Procurement } \\
\text { and Repair of adequate } \\
\text { facilities } \\
\text { 2. Governance: } \\
\text { a. Leadership (Strong } \\
\text { Headmaster leadership) } \\
\text { b. Transparency and } \\
\text { accountable finance } \\
\text { 3. Community Participation Send } \\
\text { their children to madrasa, } \\
\text { contribution of thought, funding } \\
\text { and supervision }\end{array}$ & $\begin{array}{l}\text { a. Achieving the vision and mission is not optimal, it } \\
\text { still needs to be socialized } \\
\text { b. Student recruitment uses an online system and thus } \\
\text { creates transparency and quality } \\
\text { c. The same weighting (50\%) shows the balance of the } \\
\text { curriculum, but general content is paid more attention } \\
\text { in line with the target for acceptance at the next level } \\
\text { d. The teacher of each lesson is linear and is quite good } \\
\text { and adequate. Likewise, administrative staff and } \\
\text { employees are quite fit to serve the needs } \\
\text { e. Learning support facilities are still inadequate in } \\
\text { accommodating the potential of students }\end{array}$ \\
\hline
\end{tabular}

\section{Conclusions}

Based on the results of observations, interviews and documentation studies with several elements in MTsN 2 Bogor it can be concluded that the planning and management quality processes have been carried out and applied well so that the conditions of madrasas to realize the madrasa models are adequate with the availability of supporting factors. So that the MTsN 
2 Bogor can be used as a reference or at least a comparison for other madrassas to improve the quality of education. The management functions of education that have been carried out at MTsN 2 Bogor are maximally proof that this madrasa is a plus school that is becoming a trend now and much in demand by the community.

Likewise, the output of madrasas is quite good with the achievement of several achievements, although not yet optimal, for example, only a few graduates who continue to a better level, the rest go to school / madrasas around the district.

The school components provided by MTsN which include curriculum and teaching programs, education staff, students, infrastructure, finance, and community relations have been well managed, so that the achievement of educational goals is very great opportunities.

Madrasas can compete with schools and can produce quality output according to the demands of the times if the management is managed with quality-oriented. Managers are expected to seriously meet the elements of management standards and continuously improve quality by paying attention to aspects of quality in all fields.

\section{Acknowledgements}

This article could not have been realized without the help of the Bogor Babakansirna madrasa manager, so we thank you. And to all those who have helped the smoothness of conducting research, thank you.

\section{References}

[1] Ariani, DW, 2000. Quality Management, Yogyakarta: Atma Jaya University.

[2] Biklen and Bogdan, 1992. Qualitative Research For Education. Boston: Allya and Bacon. Inc.

[3] Fadjar, A.M. 2008. Vision of Islamic Education Reform. Jakarta: LP3NI.

[4] Hoy, W. K., and Miskel, C. G, 2008. Educational Administration, Theory, Research, and Practice. Boston: Mc Grow Hill.

[5] Maesyaroh, 2003. Education Management, Substantive Analysis and Its Application in Educational Institutions. Malang: Malang State University.

[6] Malcolm and Helen, 1994. Total Quality Management for School. London: Cassel.

[7] Moleong, Lexy. J, 1994. Qualitative Research Methodology. Bandung: PT.Remaja Rosdakarya.

[8] Rahim, Husni, 2001. New Directions of Islamic Education in Indonesia, Jakarta: Logos

[9] Rusyan, Tabrani, 1997. Elementary School Management. Jakarta: CV. Argita.

[10] Sallis, Edward, 1993. Total Quality Management in Education. Philadelphia, USA: Kogan Pages Education Management Series.

[11] Scheerens, Jap, 2003. Making Schools Effective. Translator Abas Jauhari. Jakarta: Logos. Original text: Improving School Effectiveness. UNESCO (2000)

[12] Soetopo, Hidayat, 2003. Education Management. Malang State University.

[13] Subhan, Arief, 2012. 20th Century Indonesian Islamic Education Institute; The struggle between Modernization and Identity, Jakarta: Kencana Prenada Media Group

[14] Sukmadinata, Nana Syaodih, et al, 2008. Quality Control in Secondary School Education. Bandung: Refika Aditama

[15] Sudarwan, Danim, 2003. School-Based Management Threats of Improving School Quality Through Community Empowerment and Application of the Kaizen Principle. Bengkulu: PPs Bengkulu University.

[16] Suyatno, Thomas, 2002. "The Quality of High Schools". Dissertation, Jakarta: PPs UNJ. 
[17] Syafarudin, 2002. Integrated Quality Management in Education; Concepts, Strategies, and Applications. Jakarta: Grasindo.

[18] Tilaar, H.A.R, 2002. Fixing National Education. Jakarta: PT. Rineka Cipta.

[19] , 2002. New Paradigm of National Education. Jakarta: Rineka Cipta.

[20] RI Law number 20 of 2003 concerning the national education system. Bandung: Media focus, 2003.

[21] Wahab, Abdul Azis, 2007. Anatomy of Educational Organization and Leadership (Study of the Organization and Management of Educational Organizations). Bandung: Alfabeta.

[22] Lisadiyah, 2009. The Effectiveness of Madrasa Committee Performance in Improving the Quality of Education. EDUCATION: Journal of Religious and Religious Education Research, VII (2).

[23] Sopandi, E., 2011. Evaluation of MTs-SA (One Roof) Implementation. EDUCATION: Journal of Religious and Religious Education Research, 9 (2). Retrieved from https://jurnaledukasikemenag.org/index.php/edukasi/article/view/287/237

[24] Stufflebeam,D.L.,\&Coryn,C.L.S,2014.Evaluation, Theory, Model \& Applications

[25] Lopes, J., 1999. Paper templates. In TEMPLATE'06, 1st International Conference on Template Production SCITEPRESS.

[26] Smith, J., 1998. The book, The publishing company. London, $2^{\text {nd }}$ edition. 